\title{
1 Proteomic Analysis of ACE Inhibitory Peptides extracted from Fermented Goat Milk
}

2 Muhammad Zohaib Aslam ${ }^{1}$, Sana Shoukat ${ }^{1}$, Zhao Hongfei $^{1}$, Zhang Bolin ${ }^{1}$

$3{ }^{1}$ Beijing Key Laboratory of Forest Food Processing and Safety, Beijing Forestry University,

$4 \quad 100083$ Beijing, China.

5 Corresponding Author: Zhang Bolin

6 bolinzhang000@gmail.com

\section{Abstract}

8 Protein extracted from goat milk was hydrolyzed with LH (Lactobacillus Helveticus-cicc22171).

9 Angiotensin Converting Enzyme (ACE) inhibitory peptides were purified from fermented samples

10 of goat milk protein with LH by optimizing incubation time to 8 hours (S-8), 16 hours (S-16), 24

11 hours (S-24) and 36 hours (S-36), via ultrafiltration. Molecular weight cut-off; 10000 Da (PM-10)

12 membrane was used to perform size exclusion chromatography. Sample with $24 \mathrm{~h}$ incubation time

13 was considered as best hydrolyzed as compared to others, by applying Nin-Hydrin reaction and

14 SDS-PAGE analysis. ACE inhibitory assay validated the authenticity of S-24 in inhibiting ACE,

15 in vitro. Furthermore, Q executive Hybrid Quadrapole-Orbitrap Mass Spectrometry was used to

16 determine molecular structure and amino acid sequence of ACE inhibitory peptides. Two protein

17 groups VLPVPQKAVPQ and VLPVPQKVVPQ containing PVP, VVP along with one most

18 abundant peptide TQTPVVVPPFLQPEIMGVPKVKE containing VPP has been identified with

19 highest ACE inhibitory activity on the basis of intensity, small structure and higher concentration

20 of hydrophobic and aromatic amino acids. Fermented goat milk containing these novel bioactive

21 peptides, can be used as nutraceuticals to inhibit ACE and control hypertension. 
22 Keywords: ACE- inhibitory peptides; Hypertension; Identification; Purification; Fermented; Goat

23 Milk.

\section{1. Introduction}

25 Continual rise in blood pressure is defined as Hypertension (1). Hypertension is graded as the

26 most repeatedly cardiovascular risk factor with the severity of $25-30 \%$ across the globe (2).

27 Improper management of hypertension claimed seven million human lives along with 64-million

28 life long disability worldwide (3). Genetic disposition, aging, overweight, lifestyle and nutrition

29 can be considered as important factor of developing hypertension. Some diseases are also involved

30 in creating hypertension, like Diabetes, Kidney disease, Pheochromocytoma, Cushing syndrome,

31 congenital adrenal hyperplasia. Some medications like oral contraceptives, hormone therapy

32 for menopause, and excessive intake of alcohol are contributor in developing hypertension along

33 with other factors (4). Angiotensin I-converting enzyme (ACE; kininase II; EC 3.4.15.1) is

34 considered as main root cause of hypertension that is carboxy-dipeptidyl-metallopeptidase and

35 main linked enzyme of renin angiotensin system. It is involved in regulation of peripheral blood

36 pressure. It mainly catalyzes the production of angiotensin-II from angiotensin-I (a

37 vasoconstrictor) and inactivation of the vasodilator bradykinin $(5,6)$.

38 It has been known long ago about the importance of diet for human health. Recent studies

39 concluded that diet is involved in the reduction of disease $(7,8)$. Milk protein is a bioactive

40 component of milk. Along with energetic and nutritional value of milk protein, it serves as

41 physiological regulator that is involved in reducing blood pressure by inhibiting the ACE (9-12).

42 Studies confirmed that, individual with less milk consumption van have greater risk of

43 hypertension. Many scientists have approved that milk proteins not only contain energetic and

44 nutritional functions, but also can act as physiological regulators $(9,10)$. Scientists mainly focused 
45 on casein or whey protein to produce ACE inhibitory peptides; these peptides can be released

46 within sequence of the parent protein and can be hydrolyzed by enzymes or food processing.

47 Fermentation of milk also enhances its nutritional value through improved bioavailability of

48 nutrients and production of substances that have a biological function (13). Antihypertensive

49 peptides are the most, well studied among bioactive peptides. Bioactive peptides from bovine milk

50 are not a topic of interest for most of the scientific community due to the extensive work. Now it is

51 time to explore alternative sources like goat or sheep milk to extract bioactive peptides (14). Due

52 to difference in casein contents, goat milk is considered better than cow milk (15).

53 This study is designed to evaluate the role of fermented goat milk (Guanzhong Goat) milk,

54 hydrolyzed by LH in reducing hypertension with preconditions of optimizing incubation time

55 along with identification and purification of ACE inhibitory peptides on the basis of peptide

56 structure, intensity of peptides and Aromatic and hydrophobic peptide concentration.

\section{2. Materials and Methods}

\section{2.1. Materials}

59 Hippuryl-L-histidyl-L-leucine (Hip-His-Leu), purified rabbit lung ACE were purchased from

60 Sigma Chemical Co. Ltd. Real Band 3-color high Range Protein Marker (9-245kDa) of reagent

61 grade was purchased from BBI Life Sciences (Sangon Biotech Co. Ltd). Laboratory of Food

62 Sciences (Beijing Forestry University) kindly donated stock culture of LH.

\section{2.2. Ethics statement}

64 All policies mentioned in the code of ethical committee (Beijing Forestry University) for the use

65 and care of animals, were adopted and animal ethics committee of Beijing Forestry University 
66 approved the study design. Furthermore, Livestock department of Shaanxi province facilitated for

67 milking process.

\subsection{Milk Collection and Preparation of Samples}

69 Fresh Goat milk from apparently healthy and uninfected guanzhong goats was collected from 70 guanzhong area of Shanxi Province in China. Disinfectant solution (Safflon 20\%) was used to

71 wash the udder before milk collection. Autoclaveable plastic containers $(1000 \mathrm{~mL})$ were used for

72 the collection of samples and sterilized at $121^{\circ} \mathrm{C}$ for $20 \mathrm{~min}$ (16). Whole milk was converted into

73 skim milk by centrifugation at $4000 \mathrm{~g}$ for $10 \mathrm{~min}$ at $15^{\circ} \mathrm{C}$ and then stored at $-20^{\circ} \mathrm{C}$. Freeze-drying

74 of skim goat milk was performed by Detianyou FD-1 Freeze Dryer (China Based Company). The

75 freeze-dryer was programmed to operate at $-50^{\circ} \mathrm{C}$ with a vacuum pressure of 20 pa (Pascal). After

76 the end of freeze- drying cycle, dried milk was sealed under vacuum and stored at $5^{\circ} \mathrm{C}$ until

77 further analysis (17).

78 Department of Food Sciences at Beijing Forestry University maintained stock culture of LH.

79 Before experimental use, De Man, Rugosa and Sharpe (MRS) culture medium was prepared and

80 stock culture was propagated for 16 to $18 \mathrm{~h}$ at $37^{\circ} \mathrm{C}$. Hemocytometer was used to calculate

81 bacterial colonies and cells were harvested by centrifugation at $6000 \mathrm{~g}$ for $10 \mathrm{~min}$ at $4{ }^{\circ} \mathrm{C}$ and

82 washed three times with distilled water.

83 Goat milk Protein was co-cultured with the $\mathrm{LH}\left(1 \times 10^{9} \mathrm{cfu} / \mathrm{mL}\right)$ at the ratio of $10: 2 \mathrm{~mL}$

84 respectively. Moreover, Samples were incubated for the interval of 8, 16, 24 and 36 hours.

85 Furthermore, samples were centrifuged at $15000 \mathrm{~g}$ for 30 minutes and supernatant was filtered by

86 using $0.45 \mu 1$ (microliter) filter tip and stored at $-20^{\circ} \mathrm{C}$ for further analysis.

\section{2.4. Degree of hydrolysis}


88 Nin-Hydrin reaction was applied to estimate the degree of hydrolysis of protein into peptides. To

89 prepare $20 \mathrm{~mL}$ solution Reagents were prepared according to standard protocol with $2 \mathrm{~g}$ (gram) of

$90 \mathrm{Na}_{2} \mathrm{HPO}_{4} \cdot 10 \mathrm{H}_{2} \mathrm{O}, 1.2 \mathrm{~g} \mathrm{NaH} \mathrm{PO}_{4} \times 2 \mathrm{H}_{2} \mathrm{O}, 0.1 \mathrm{~g}$ Nin-Hydrin and $0.06 \mathrm{~g}$ Fructose.

91 Each sample (S-8, S-16, S-24 and S-36) with $0.05 \mathrm{~mL}$ quantity was added into $15 \mathrm{ml}$ of deionized

92 water to dilute it further. Aliquot measuring in $0.5 \mathrm{~mL}$ was taken and mixed with $1 \mathrm{ml}$ reagent

93 solution. Mixture was allowed to heat on $100^{\circ} \mathrm{C}$ for 15 minutes. After heating, the color of

94 samples turned into purple and its wavelength is determined at 570nm by using Spectrophotometer

95 (PGENERAL T-6 New century, China).

96 2.5. SDS-PAGE (sodium dodecyl sulfate-polyacrylamide gel electrophoresis)

97 Samples were dissolved into $50 \mathrm{mM}$ Tris-HC1 with $\mathrm{pH} 6.8$, containing 2\% (w/v) SDS, $2 \mathrm{mM}$

98 EDTA, 10\% (v/v) glycerol and 0.1\% (w/v) bromophenol blue. When dissociation was needed,

$990.1 \%(\mathrm{w} / \mathrm{v})$ dithiotreitot (DTT) was freshly added to the same buffer and the sample solution was

100 heated at $95^{\circ} \mathrm{C}$ for 15 minutes. Polyacrylamide slab gels were cast and electrophoretic separations

101 was carried out using a Bio-Rad Mini-Protein II Electrophoresis Cell System. Slab gel

102 electrophoresis was performed in a 15\% separating gel with a 5\% stacking gel. Separating gel and

103 stacking gels was prepared according to standard protocol.

104 Polyacrylamide gels were stained with $0.25 \%(\mathrm{w} / \mathrm{v})$ Coomassie R-250 Blue in 50\% (v/v) methanol 105 and 7.5\% (v/v) acetic acid for 15-30 min, according to discontinuous buffer system (18). Gel was 106 destained in $20 \%(\mathrm{v} / \mathrm{v})$ methanol and $7.5 \%$ acetic acid. 
108 Samples were filtered with $10000 \mathrm{Da}$ cut-off membranes. Solution was further purified with gel

109 filtration by using Sephadex G-15 column $(1.6 \times 90 \mathrm{~cm})$ and eluted with deionized water. A

110 Fraction of $5 \mathrm{~mL}$ from each vial was collected at the flow rate of $0.5 \mathrm{~mL} / \mathrm{min}$. Absorbance of

111 fraction was calculated at $280 \mathrm{~nm}$ by using spectrophotometer.

112

\section{2.7. Assay for ACE inhibitory activity}

114 ACE-inhibition activity of the goat milk peptides was measured according to (19) with some

115 modification. Briefly, $180 \mu$ l Of HHL buffer (5 mM Hip-His-Leu in $0.1 \mathrm{M}$ borate buffer containing

$116 \quad 0.3 \mathrm{M} \mathrm{NaCl}, \mathrm{pH} 8.3$ ) was mixed with $50 \mu \mathrm{l}$ of sample solution. The mixture of sample and buffer

117 was incubated for $3 \mathrm{~min}$ at $37^{\circ} \mathrm{C}$. Moreover, the reaction was started by the addition of $20 \mu \mathrm{l}$ of

118 ACE (dissolved in distilled water, 0.1 units $/ \mathrm{ml}$ ). The whole mixture was incubated again for 40

$119 \min$ at $37^{\circ} \mathrm{C}$. Adding $200 \mu \mathrm{l}$ of $1.0 \mathrm{~N} \mathrm{HCl}$ has stopped the reaction. The absorbance was measured

120 at $228 \mathrm{~nm}$ using a spectrophotometer to estimate ACE activity. The extent of inhibition was

121 calculated as follows:

$122 \quad$ ACE inhibitor rate $=(B-A / B-C) 100$

123 Where $\mathrm{A}$ is the absorbance in the presence of ACE and with the ACE-inhibitory component, B is

124 the absorbance with ACE and without the ACE-inhibitory component; $\mathrm{C}$ is the absorbance without

125 ACE or ACE inhibitor component.

\section{$126 \quad$ 2.8. Identification of peptides}

127 Q executive Hybrid Quadrapole-Orbitrap Mass Spectrometry was used to identify peptides in the 128 sample. This is a bench top LC-MS/MS system combines quadruple precursor ion selection with 
129 high-resolution, accurate-mass Orbitrap detection; mass range from 50-6000 m/z and scan range

130 up to $12 \mathrm{~Hz}$. Chromatographic separations were performed on C18 column $(300 \mu \mathrm{m}$

131 i.d. x 5mm, packed with Acclaim PepMap RSLC C18, $5 \mu \mathrm{m}, 100 \AA$, Nano Viper, Acclaim

132 PepMap $75 \mu \mathrm{m}$ X 150mm, C18, $3 \mu \mathrm{m}, 100 \mathrm{~A})$. The mobile phase consisted of $0.1 \%$ formic acid in

133 pure water (Solvent A) and 0.1\% formic acid, 80\% ACN (Solvent B), formed with gradient

134 elution with following parameters: 0-5 min, 0-5\% B; 5-25 min, 5-5\% B; 25- 30 min, 5-50\% B; 25-

$13530 \%, 50-90 \% \mathrm{~B} ; 30-35 \mathrm{~min}, 90 \% \mathrm{~B} ; 35-45 \mathrm{~min}, 5 \% \mathrm{~B}$. The total run time was 40 min with a

136 constant flow rate of $300 \mathrm{~nL} / \mathrm{min}$.

137 Some parameters in Orbitrap were as follows: spray voltage, $2.0 \mathrm{kV}$; capillary temperature, 250

$138{ }^{\circ} \mathrm{C} ; \mathrm{m} / \mathrm{z}$ (mass to charge ratio) range (ms), 350 to 1800. AGC (Automatic gain control) ion

139 injection targets for first level FTMS (Fourier Transform Mass Spectrometry) scan were 70,000

140 (40 ms max injection time) with $3 \mathrm{e} 6 \mathrm{AGS}$ target and for second level mass spectrometry were

141 17,500 (60 ms max injection time) with 1e5 AGS target; 27NCE (normalized collisional energy)

142 and 20 TopN.

\section{2.9. Database Search}

144 The original mass spectrum file was processed by MM File Conversion software. This PC 145 (personal computer) version is a software suite for protein identification/characterization, cross-

146 link/disulfide search, iTRAQ/TMT quantitation, and N/SILAC quantitation using LC-MS/MS to 147 obtain the MGF format file, and then using MaxQuant searched the database. MaxQuant is one of 148 the most frequently used platforms for mass-spectrometry (MS)-based proteomics data 149 analysis.

150 3. Results and Discussion 


\section{3.1. Protein Degradation}

152 In order to obtain Goat milk protein hydrolysates, LH were used to break down the protein into

153 peptides. Degree of protein degradation into peptides by hydrolysis is called degree of hydrolysis.

154 It is one of most authentic mechanism to measure the hydrolysis process (20). It is also used as

155 indicator of comparing different protein hydrolysates (21). Protein concentration decreased with

156 its degradation into peptides as the incubation time rises and maximum hydrolysis was observed

157 after 24 hours. DH determined at various incubation times with LH is shown in Fig. 2.

158 Results of DH show the gradual decrease in protein contents from 8 h to 24 and it remains almost 159 constant from 24 to $36 \mathrm{~h}$, with negligible difference in protein degradation. It can be assumed on 160 the basis of $\mathrm{DH}$ that sample should be fermented for 24 hours to get best hydrolysis rather than 161 increasing time, because it can not make big difference in matter of peptides formation.

162 A representative SDS-PAGE electrophoregram of the samples with different incubation time is

163 shown in Figure 3. This result endorses the outcome of Figure 2.

164 Major changes while performing SDS-PAGE included decrease in several bands indicated greater 165 enzymatic breakdown by 24 -h incubation. Furthermore, $10 \%$ acrylamide gel was used to identify 166 the Small molecular parts. Samples with $24 \mathrm{~h}$ and $36 \mathrm{~h}$ incubation time, represented almost same 167 picture of hydrolysis that indicated importance of 24-h incubation sample.

\section{3.2. Ultrafiltration}

169 Filtration of samples with PM-10 membrane (molecular weight cut-off; $10 \mathrm{kDa}$ ) was done to

170 further purify ACE inhibitory peptides. Samples were lyophilized after purification and 171 concentrated in distilled water. 
172 Different steps in separation and purification techniques were recommended (22). For this

173 purpose, Sephadex G-25 column was used to load the sample and peptides with low molecular

174 mass (under $3000 \mathrm{Da}$ ) were separated. It indicates the role of small peptides in obstruction of ACE

175 and these results were in agreement with the previous work $(23,24)$.

\section{3.3. ACE Inhibition Pattern}

177 All four samples were tested to evaluate their potency to inhibit ACE production by applying 178 ACE assay, in vitro. Although, It was confirmed that S-24 was best hydrolyzed by previous tests 179 and expected to show better inhibitory activity due to greater concentration of hydrolyzed protein, 180 but all samples were tested against ACE to further authenticate results. A clear trend of increasing 181 ACE inhibitory activity has been observed with increasing incubation time of fermented samples, 182 and after 24 hours, increasing trend was as slow as negligible. It was clear after running assay that 183 S-24 was the sample to further evaluate for its peptides profile that were showing greater ACE 184 inhibitory activity as compared to others. Figure 4, indicates the increasing trend of ACE 185 inhibition percentage with increasing time. After $8 \mathrm{~h}$ of incubation $51.11 \%$ ACE inhibitory 186 percentage was observed that increased gradually with time and after $16-\mathrm{h}$, it rose to $62.23 \%$. 187 Further increase in time to incubate samples, resulted in increase in inhibition of ACE by $72.32 \%$ 188 after $24 \mathrm{~h}$ and $73.98 \%$ after $36 \mathrm{~h}$.

\section{3.4. Identification of Peptides}

190 Five most abundant Peptides with two unique protein groups have been identified as shown in 191 table 1.

192 Table 1 


\begin{tabular}{|c|c|c|c|c|c|}
\hline $\begin{array}{l}\text { Peptide } \\
\text { ID }\end{array}$ & Peptide Sequences & Mass (Da) & $\begin{array}{l}\text { Intensity } \\
\left(10^{8}\right)\end{array}$ & $\begin{array}{l}\text { C-term cleavage } \\
\text { window }\end{array}$ & $\begin{array}{l}\text { N-term } \\
\text { cleavage } \\
\text { window }\end{array}$ \\
\hline 1073 & $\begin{array}{l}\text { TQTPVV } \\
\text { GVPPFLQPEIM }\end{array}$ & 2548.397 & 3.46 & $\begin{array}{l}\text { MGVPKVKETM } \\
\text { VPKHKE }\end{array}$ & $\begin{array}{l}\text { LPQNILPLT } \\
\text { QTPVVVP }\end{array}$ \\
\hline 1045 & TLTDVEKL & 917.506 & 3.13 & $\begin{array}{l}\text { TLTDVEKLHLPL } \\
\text { PLVQ }\end{array}$ & $\begin{array}{l}\text { PFTESQSLT } \\
\text { LTDVEKL }\end{array}$ \\
\hline 1136 & VLPVPQKAVPQ & 1174.707 & 3.01 & $\begin{array}{l}\text { VPQKAVPQRDM } \\
\text { PIQAF }\end{array}$ & $\begin{array}{l}\text { VLSLSQPK } \\
\text { VLPVPQKA }\end{array}$ \\
\hline 826 & REQEELNVVGE & 1300.625 & 2.98 & $\begin{array}{l}\text { EELNVVGETVE } \\
\text { SLSSS }\end{array}$ & $\begin{array}{l}\text { CLVALAIA } \\
\text { REQEELNV }\end{array}$ \\
\hline 1138 & VLPVPQKVVPQ & 1202.738 & 2.72 & $\begin{array}{l}\text { VPQKVVPQRDM } \\
\text { PIQAF }\end{array}$ & $\begin{array}{l}\text { VLSLSQPK } \\
\text { VLPVPQKV }\end{array}$ \\
\hline
\end{tabular}

194 Table 1. Peptide ID was assigned on the basis of MaxQuant search results, and Peptide sequence 195 was obtained in the result of running MS/MS. 
196 They were categorized on the basis of intensity and abundance of peptide in the sample, presence

197 of hydrophobic and aromatic amino acids and structure of amino acid sequence. Peptide sequence,

198 with molecular weight of 2532.4026 Da and PID-1073 (peptide identification number), was

199 categorized as the most abundant peptide on the basis of Mass to Charge ratio $(\mathrm{m} / \mathrm{z})$ which was

200 recorded 1267.72 in figure 5 (A). It was identified several times with retention time of 41.785 ,

$20141.824,44.933$ and $44.944 \mathrm{~min}$. Low molecular weight peptide (917.506 Da) with the retention

202 time of $25.411,27.137$ and 27.93 min was identified thrice in S-24. Mass spectrum of PID-1045

203 was $459.76 \mathrm{~m} / \mathrm{z}$ shown in figure 5 (B). Third and fifth peptides with PVP, VVP sequence

204 contested for potential ACE inhibitor peptides. PID-1136 with two times spectroscopic

205 identification and retention time of 21.494 and 21.519 min while PID-1138 with one time

206 identification with retention time of $25.318 \mathrm{~min}$, was explained in figure 5 (C) and 5 (E).

207 Molecular weight of PID-1136 and 1138 was 1174.707 Da and 1202.738 Da respectively. Within

208 Unique protein groups, PID-1136 with leading razor protein number Q712N8 was identified after

20935 scans containing 6 isotopic peaks while PID 1138 with leading razor protein number Q95L76,

210 was identified after 52 scans containing 5 isotopic peaks. Furthermore, PID 826 was identified

211 once with retention time of $21.648 \mathrm{~min}$. Its molecular weight was 1300.625 Da explained

212 spectroscopically in figure 5 (D). PID 826 with leading razor protein number Q95L76 was

213 identified once after 26 scans containing 6 isotopic peaks.

215 It was reported earlier that many ACE inhibitory peptides consist of 2-12 amino acid residues

216 (25), and our samples indicates that out of five most abundant peptides, Four (TLTDVEKL,

217 VLPVPQKAVPQ, REQEELNVVGE, VLPVPQKVVPQ) consist of less than 12 peptides with 218 low molecular weight, which is in accordance to our findings. Short chain peptides are less prone 
219 to proteolytic enzymes of small intestine after oral administration, while easily absorbable to the

220 absorptive cells because intestinal cells are restricted to absorb ultra-small peptides (26). While an

221 other study was conducted by running experiments on rats and concluded that peptides larger than

222 ultra-small peptides can also passed through small intestine wall but absorption mechanism of

223 larger peptides is not yet explained properly that needs to be explored (27). On the other hand,

224 peptides detected in S-24 showed ACE inhibitory activity, in vitro and it might assume that these

225 peptides will remain intact in the gut and intestine of human because of their smaller structure with

226 low molecular weight rather than degrading by proteolytic enzymes and might be absorbed easily

227 through intestinal cells. It was reported in 2004 that digestive enzymes are unable to break down

228 some peptides like Proline- and hydroxyproline-containing peptides and tripeptides containing the

229 C-terminal proline-proline due to resistance of those peptides (28), while higher concentration of

230 Proline in PID 1073, 1136 and 1138 respectively was identified in this study that can by-pass

231 digestive enzymes easily and make them active contestant in inhibiting ACE. Besides, peptide

232 size, there are other factors like amino acid residues and peptide sequence, may play a significant

233 role in shaping ACE-inhibitory activities. It is stated in some studies that ACE-inhibitory peptides

234 encoded in natural foods and products contain Proline, Lysine or aromatic amino acid residues

$235(29,30)$ that further supports our finding by exhibiting the presence of Lysine in all peptides with

236 higher presence of Proline in PID 1073 followed by PID 1136 and 1138. Greater quantity of

237 hydrophobic aliphatic amino acid and aromatic amino acid like Proline, Leucine, Alanine,

238 Metionine and Isoleucine, in a sample may increase the ACE-inhibitory activity (31-33), While

239 our findings are in agreement by the identification of peptides like

240 TQTPVVVPPFLQPEIMGVPKVKE and TLTDVEKL with higher concentration of aromatic and

241 hydrophobic amino acid. Methiotine, Triptophane, and Valine in P-1073, 1045, 1136 and 1138 on 
242 C-cleavage indicates the greater hydrophobicity of this peptide and greater hydrophobicity of C-

243 cleavage shows the greater ACE inhibitory activity (34). C- cleavage with Aromatic amino acid

244 and N- cleavage with Aliphatic amino acid might increase ACE inhibitory activity (35), While in

245 this study, an aromatic amino acid Tyrocine was identified in P-1045 and aliphatic amino acid

246 Leucine, Valine and Valine was identified in PID-1073, 1136 and 1138 respectively. Leucine and

247 Valine, with small N-terminal amino acids and strong hydrophobicity are more appropriate for

248 ACE inhibitory activity (36) and same amino acids were found on N-terminal of P-1073, 1136

249 and 1138.

250 4. Conclusion

251 The molecular mass of peptides (peptide length) is not the only important factor to evaluate its

252 functional activities, other factors including presence and intensity of aromatic and hydrophobic

253 amino acid and amino acid sequence also has an important role to play. In this study, fermented

254 goat milk peptides, by optimizing incubation time to 24 hours, were proved to exhibit remarkable

255 ACE- inhibitory activity. Three ACE-inhibitory peptides, PID-1073

256 (TQTPVVVPPFLPEIMGVPKVKE), PID-1136 (VLPVPQKAVPQ) and 1138

257 (VLPVPQKVVPQ) were identified by Q executive Hybrid Quadrapole-Orbitrap Mass

258 Spectrometery from S-24. Furthermore, structure analysis, intensity and presence of

259 hydrophobic/aromatic amino acid concentration provided clear picture of their mode of action. It

260 provided a basis to synthesize these peptides artificially. Goat milk peptides fermented with LH

261 after optimizing incubation time to 24 hours can be used as functional food or nutraceuticals in

262 treating hypertension.

\section{Acknowledgement}


264 I am really thankful to the Zhao Hongfei, Lecturer (Beijing Forestry University, for providing me

265 all opportunities to run experiments. This research was done with funding of Beijing Key

266 Laboratory of Forest Food Processing and Safety, School of Biological Sciences and Technology,

267 Beijing Forestry University (China).

268 Conflict of Interest: I declare no conflict of interest.

269 References

270 1. Seppo L, Jauhiainen T, Poussa T, Korpela R. A fermented milk high in bioactive

271 peptides has a blood pressure-lowering effect in hypertensive subjects. The American 272 journal of clinical nutrition. 2003;77(2):326-30.

2732 2. Kearney PM, Whelton M, Reynolds K, Muntner P, Whelton PK, He J. Global burden of 274 hypertension: analysis of worldwide data. The lancet. 2005;365(9455):217-23.

275 3. Perkovic V, Huxley R, Wu Y, Prabhakaran D, MacMahon S. The burden of blood 276 pressure-related disease: a neglected priority for global health. Hypertension. 277 2007;50(6):991-7.

278 4. Mancia G, De Backer G, Dominiczak A, Cifkova R, Fagard R, Germano G, et al. 2007 Guidelines for the management of arterial hypertension: The Task Force for the Management of Arterial Hypertension of the European Society of Hypertension (ESH) and of the European Society of Cardiology (ESC). European heart journal. 2007;28(12):1462-536.

5. Gobbetti M, Ferranti P, Smacchi E, Goffredi F, Addeo F. Production of Angiotensin-Iconverting-enzyme-inhibitory peptides in fermented milks started by Lactobacillus delbrueckiisubsp. bulgaricus SS1 and Lactococcus lactissubsp. cremoris FT4. Applied and Environmental Microbiology. 2000;66(9):3898-904.

6. Kiom J, Lee D, Chung K, Jeong S, Lee J. Characterization of antihypertensive angiotensin I-converting enzyme inhibitor from Saccharomyces cerevisiae. Journal of Microbiology and Biotechnology. 2004.

7. Groziak SM, Miller G. Natural bioactive substances in milk and colostrum: effects on the arterial blood pressure system. British Journal of Nutrition. 2000;84(S1):119-25.

8. Das UN. Nutritional factors in the pathobiology of human essential hypertension. Nutrition. 2001;17(4):337-46.

9. Schanbacher F, Talhouk R, Murray F, Gherman L, Willett L. Milk-borne bioactive peptides. International Dairy Journal. 1998;8(5-6):393-403.

10. Tomé D, Debabbi H. Physiological effects of milk protein components. International dairy journal. 1998;8(5-6):383-92.

11. Meisel H. Overview on milk protein-derived peptides. International Dairy Journal. 1998;8(5-6):363-73. 
12. Yamamoto N, Maeno M, Takano T. Purification and characterization of an antihypertensive peptide from a yogurt-like product fermented by Lactobacillus helveticus CPN4. Journal of Dairy Science. 1999;82(7):1388-93.

13. Korhonen $\mathrm{H}$, Pihlanto A. Bioactive peptides: production and functionality. International dairy journal. 2006;16(9):945-60.

14. Bernacka H. Health-promoting properties of goat milk. Medycyna Weterynaryjna. 2011;67(8):507-11.

15. Park Y, Juárez M, Ramos M, Haenlein G. Physico-chemical characteristics of goat and sheep milk. Small ruminant research. 2007;68(1):88-113.

16. Omer R, Eltinay A. Microbial quality of camel's raw milk in central \& southern regions of United Arab Emirates. Emirates Journal of Food and Agriculture. 2008:76-83.

17. Ivanova S. Dynamical changes in the trace element composition of fresh and lyophilized ewe's milk. Bulgarian Journal of Agricultural Science. 2011;17(1):25-30.

18. Laemmli UK. Cleavage of structural proteins during the assembly of the head of bacteriophage T4. nature. 1970;227(5259):680.

19. Cushman D, Cheung H. Spectrophotometric assay and properties of the angiotensinconverting enzyme of rabbit lung. Biochemical pharmacology. 1971;20(7):1637-48.

20. Adler-Nissen J. Determination of the degree of hydrolysis of food protein hydrolysates by trinitrobenzenesulfonic acid. Journal of agricultural and food chemistry. 1979;27(6):1256-62.

21. Mahmoud MI. Physicochemical and functional properties of protein hydrolysates in nutritional products. Food Technology. 1994;48:89-113.

22. Jinyu HJZYS. Progress of Antihypertensive Peptide Research [J]. Food and Fermentation Industries. 2006;6:024.

23. Astawan M, Wahyuni M, Yasuhara T, Yamada K, Tadokoro T, Maekawa A. Effects of angiotensin I-converting enzyme inhibitory substances derived from Indonesian driedsalted fish on blood pressure of rats. Bioscience, biotechnology, and biochemistry. 1995;59(3):425-9.

24. Gómez-Ruiz JÁ, Ramos M, Recio I. Angiotensin-converting enzyme-inhibitory peptides in Manchego cheeses manufactured with different starter cultures. International Dairy Journal. 2002;12(8):697-706.

25. Byun H-G, Kim S-K. Structure and activity of angiotensin I converting enzyme inhibitory peptides derived from Alaskan pollack skin. BMB Reports. 2002;35(2):239-43.

26. Matthews D, Payne J. Transmembrane transport of small peptides. Current topics in membranes and transport. 14: Elsevier; 1980. p. 331-425.

27. Roberts PR, Burney J, Black KW, Zaloga GP. Effect of chain length on absorption of biologically active peptides from the gastrointestinal tract. Digestion. 1999;60(4):332-7.

28. Vermeirssen V, Van Camp J, Verstraete W. Bioavailability of angiotensin I converting enzyme inhibitory peptides. British Journal of Nutrition. 2004;92(3):357-66.

29. Kawakami A, Kayahara H. Synthesis of leu-lys-tyr derivatives and their interaction with angiotensin I converting enzyme. Journal of Japanese Society of Nutrition and Food Science (Japan). 1993.

30. Suetsuna K, Nakano T. Identification of an antihypertensive peptide from peptic digest of wakame (Undaria pinnatifida). The Journal of nutritional biochemistry. 2000;11(9):450-4. 
344 31. Cian RE, Alaiz M, Vioque J, Drago SR. Enzyme proteolysis enhanced extraction of ACE 345 inhibitory and antioxidant compounds (peptides and polyphenols) from Porphyra 346 columbina residual cake. Journal of applied phycology. 2013;25(4):1197-206.

347 32. Chalé FGH, Ruiz JCR, Fernández JJA, Ancona DAB, Campos MRS. ACE inhibitory, 348 hypotensive and antioxidant peptide fractions from Mucuna pruriens proteins. Process 349 Biochemistry. 2014;49(10):1691-8.

350 33. Udenigwe CC, Aluko RE. Chemometric analysis of the amino acid requirements of 351 antioxidant food protein hydrolysates. International Journal of Molecular Sciences. 352 2011;12(5):3148-61.

353 34. He R, Ma H, Zhao W, Qu W, Zhao J, Luo L, et al. Modeling the QSAR of ACE-inhibitory 354 peptides with ANN and its applied illustration. International journal of peptides. 2012;2012. 355 35. Cheung H-S, Wang F-l, Ondetti MA, Sabo EF, Cushman DW. Binding of peptide 356 substrates and inhibitors of angiotensin-converting enzyme. Importance of the $\mathrm{COOH}$ 357 terminal dipeptide sequence. Journal of Biological Chemistry. 1980;255(2):401-7.

358 36. Wu J, Aluko RE, Nakai S. Structural requirements of angiotensin I-converting enzyme 359 inhibitory peptides: quantitative structure- activity relationship study of di-and tripeptides. 360 Journal of agricultural and food chemistry. 2006;54(3):732-8. 


\section{Figures Caption}

Figure 1. Graphical abstract of research.

Figure 2. Time period was indicated in hours on $\mathrm{x}$-axis while y-axis represents percentage of protein hydrolysis.

Figure 3. Molecular weight (MW) of peptides was indicated in kDa while samples with 8 $\mathrm{h}$ and $16 \mathrm{~h}$ incubation showed the presence of $10 \mathrm{kDa}$ peptides while samples with $24 \mathrm{~h}$ and 36-h incubation period showed absence of 10kDa peptides.

Figure 4. Time period in hours, is indicated on $\mathrm{x}$-axis while Y-axis represents the level of ACE inhibitory percentage.

Figure 5 (A), (B), (C), (D) and (E).

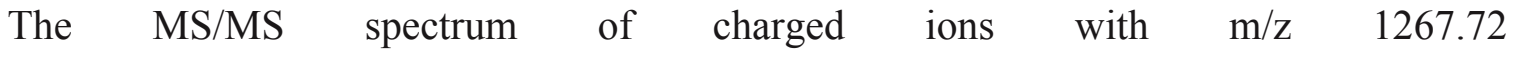
$\begin{array}{lll}\text { (TQTPVVVPPFLQPEIMGVPKVKE), } \quad 459.76 \quad \text { (TLTDVEKL), } & 588.36\end{array}$ (VLPVPQKAVPQ), 651.32 (REQEELNVVGE) and 602.38 (VLPVPQKVVPQ) have been identified (Figure 5 (A), 5 (B), 5 (C), 5 (D) and 5 (E). The MS/MS spectrum was acquired with Q executive Hybrid Quadrapole-Orbitrap Mass Spectrometery. The peptide sequence is indicated on the bottom with collision-induced fragmentation pattern. The $b$ and $\mathrm{y}$ ions are indicated in blue and red, respectively. X-axis shows the $\mathrm{m} / \mathrm{z}$ and $\mathrm{y}$-axis shows the relative abundance of each amino acid. 
Figure 1: Graphical abstract

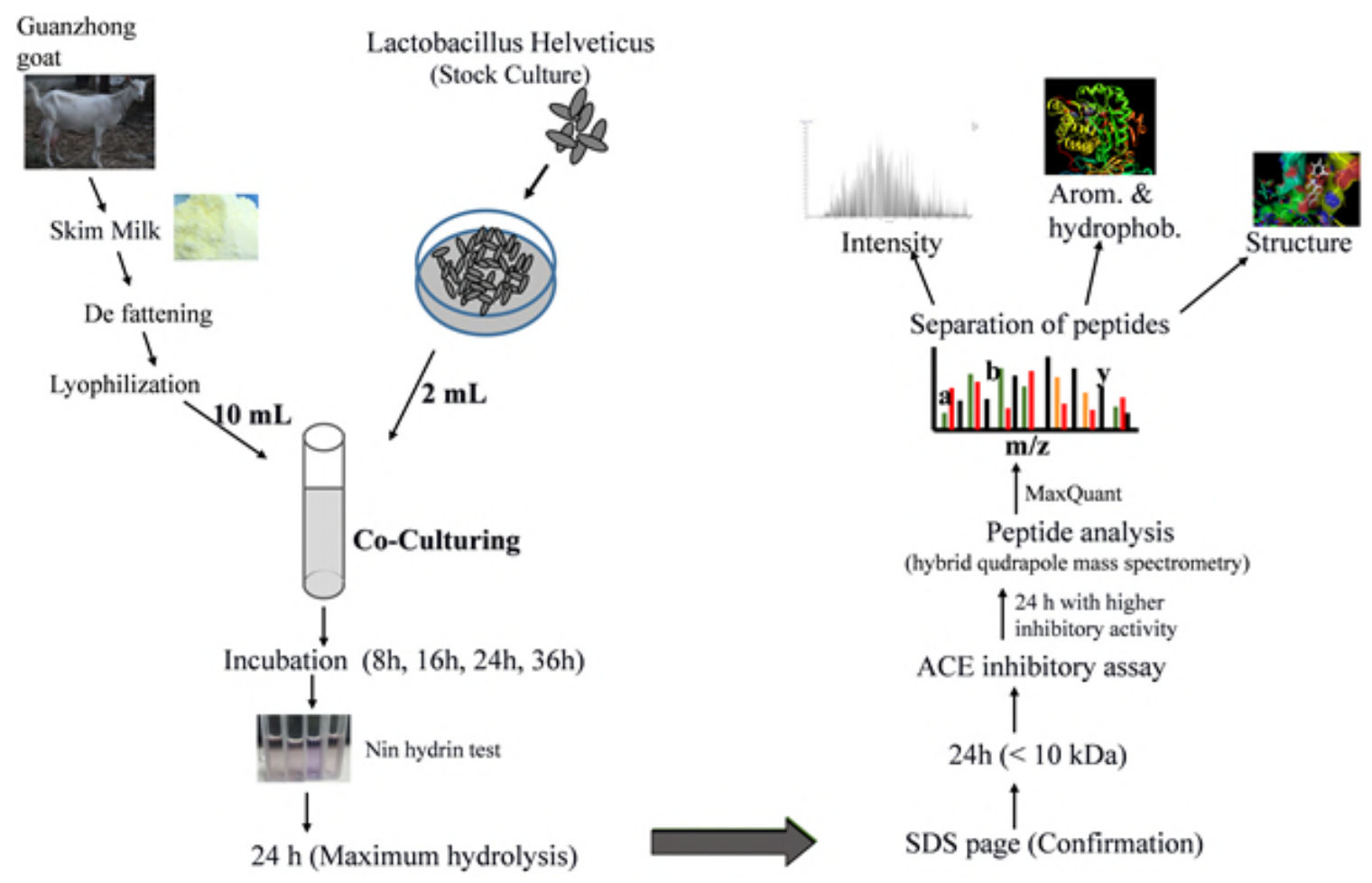

Figure 2.

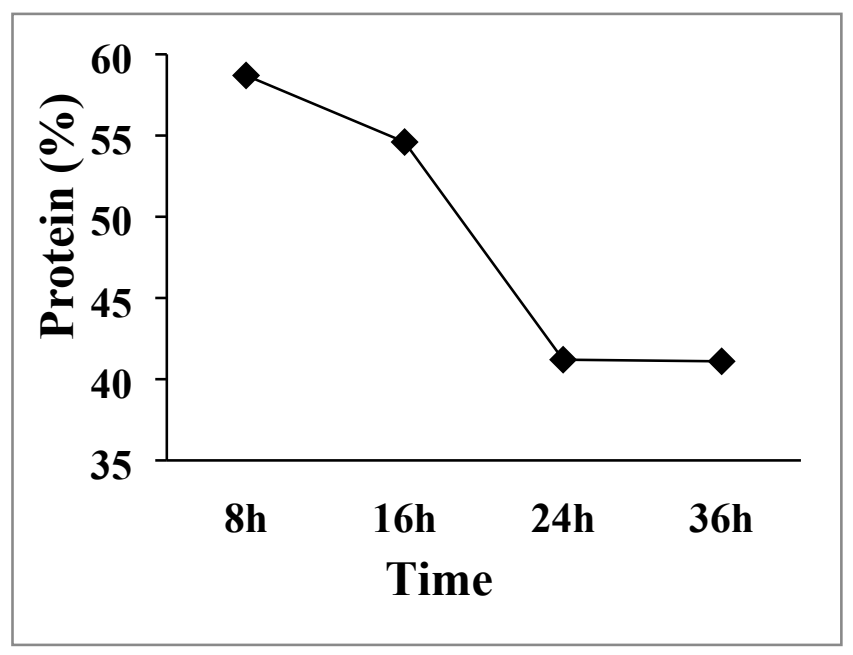


Figure 3 .

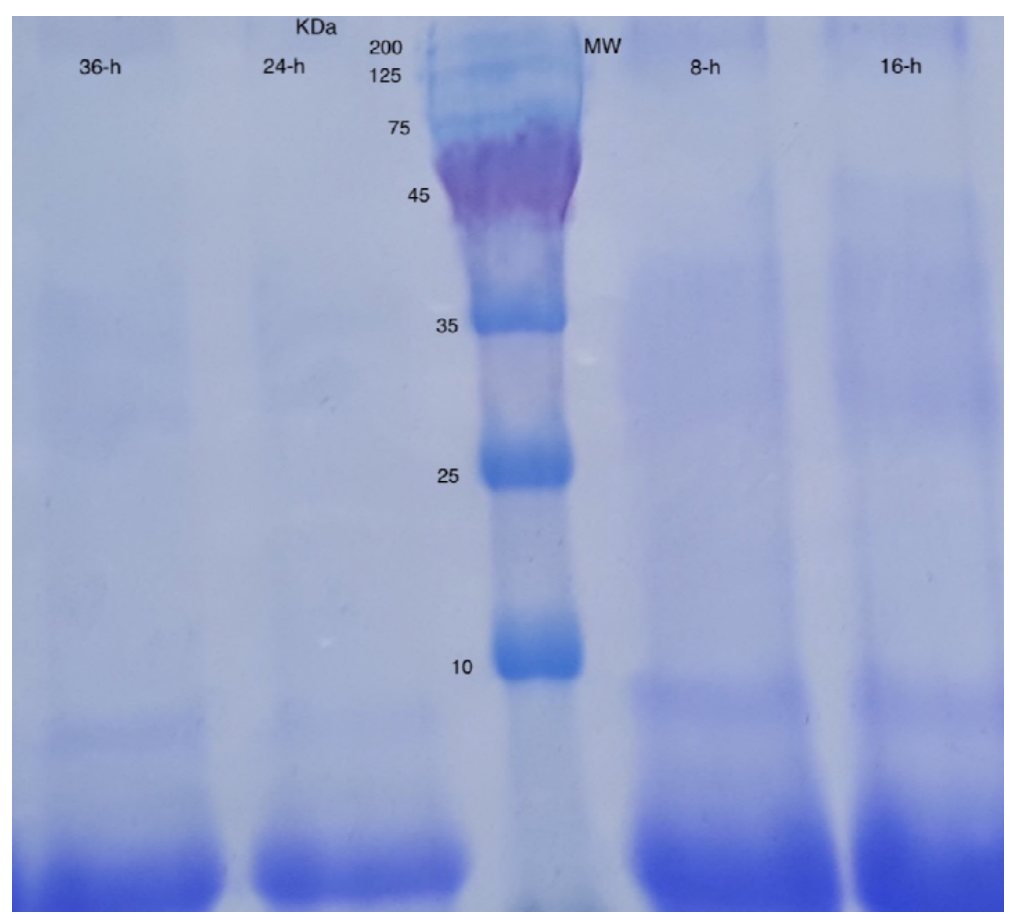

Figure 4.

\section{ACE Inhibition (\%)}

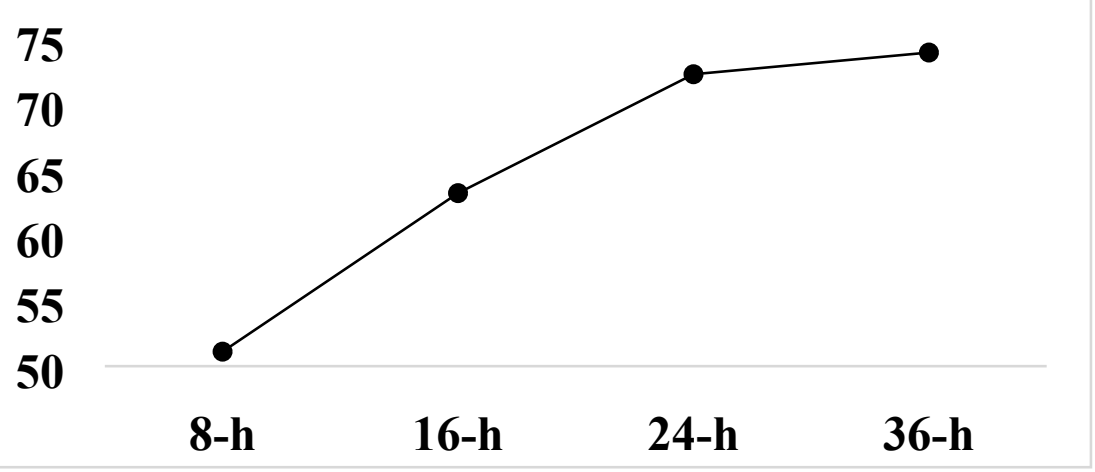


Figure $5(\mathrm{~A})$
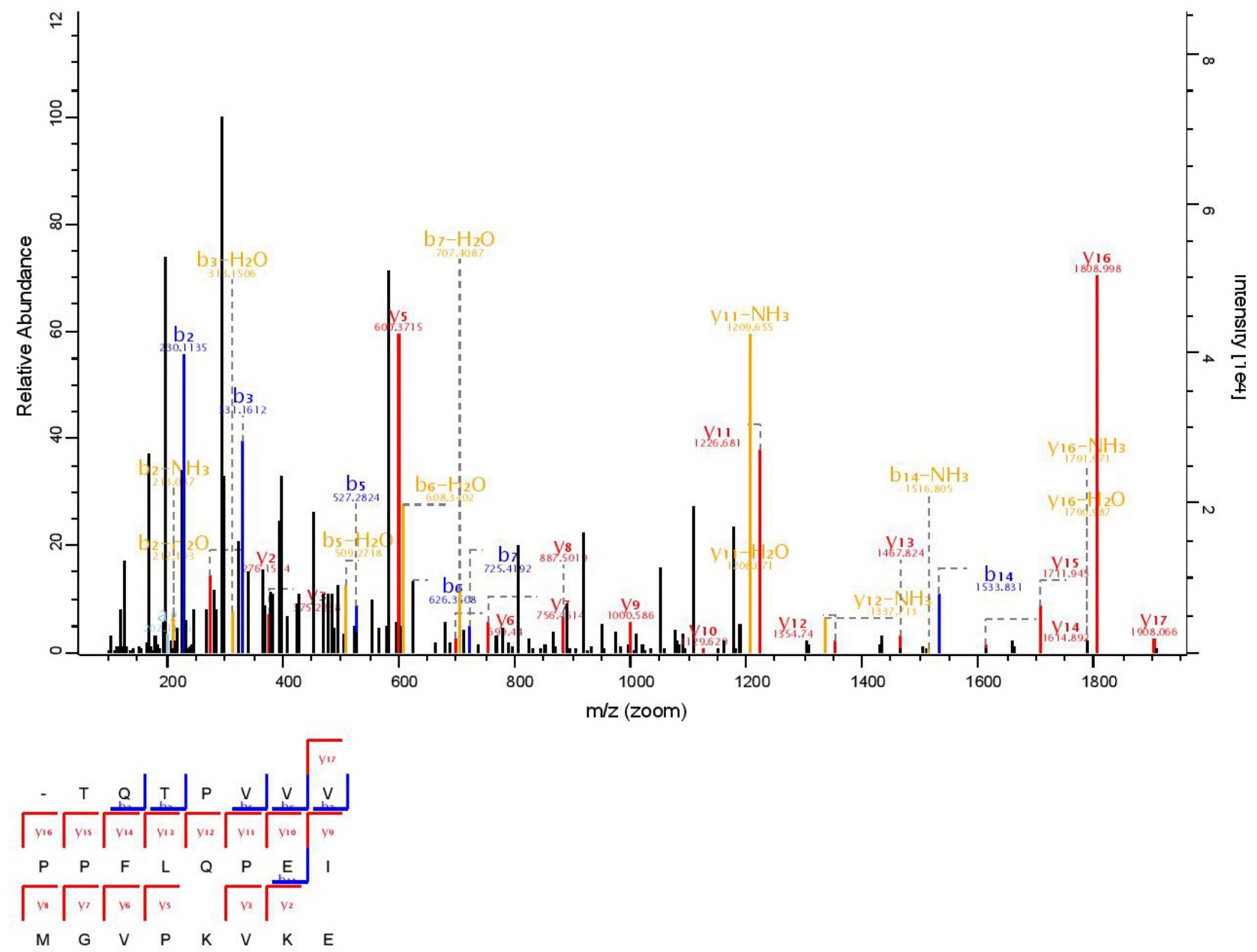
Figure 5 (B)
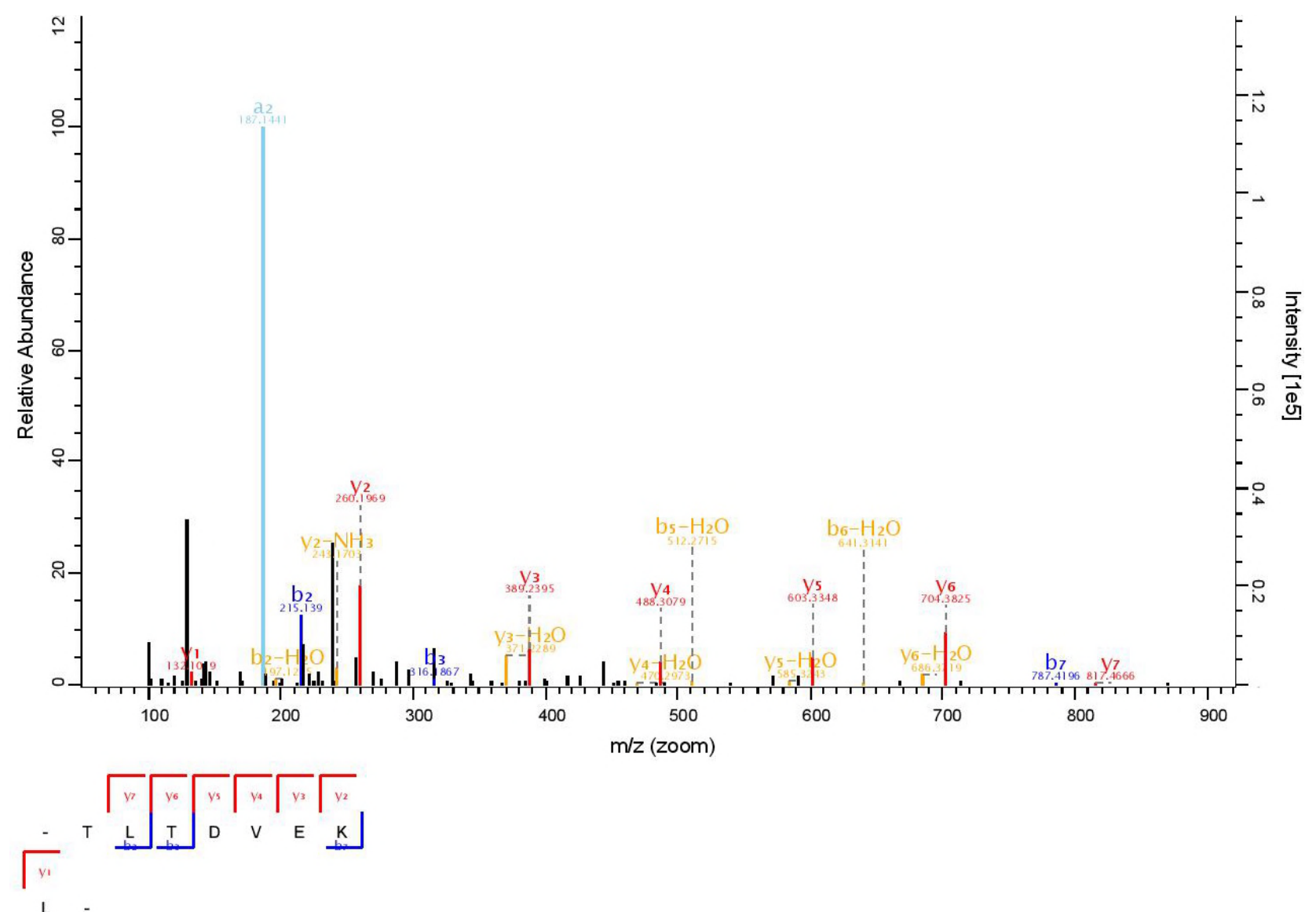
Figure 5 (C)
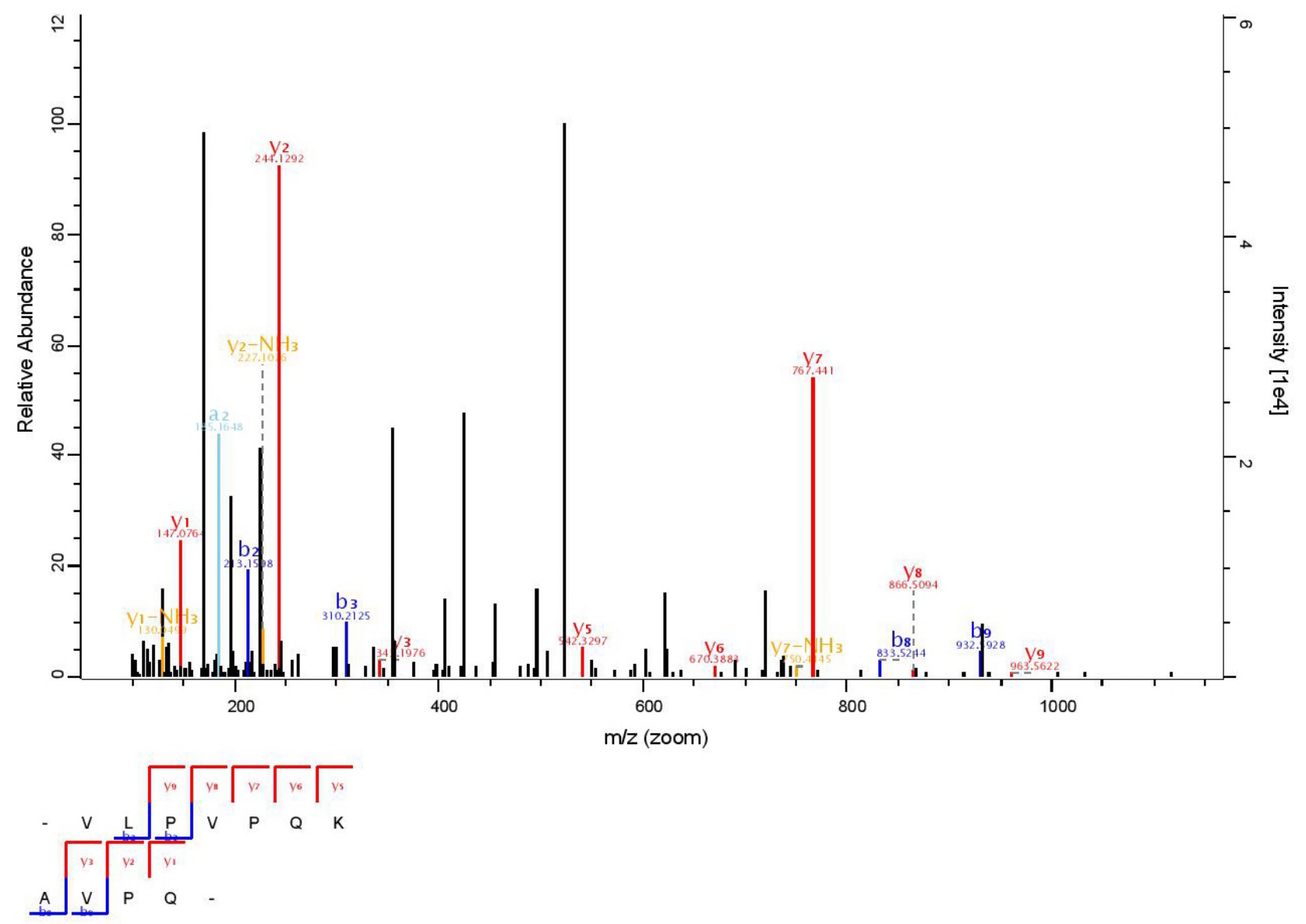
Figure 5 (D)
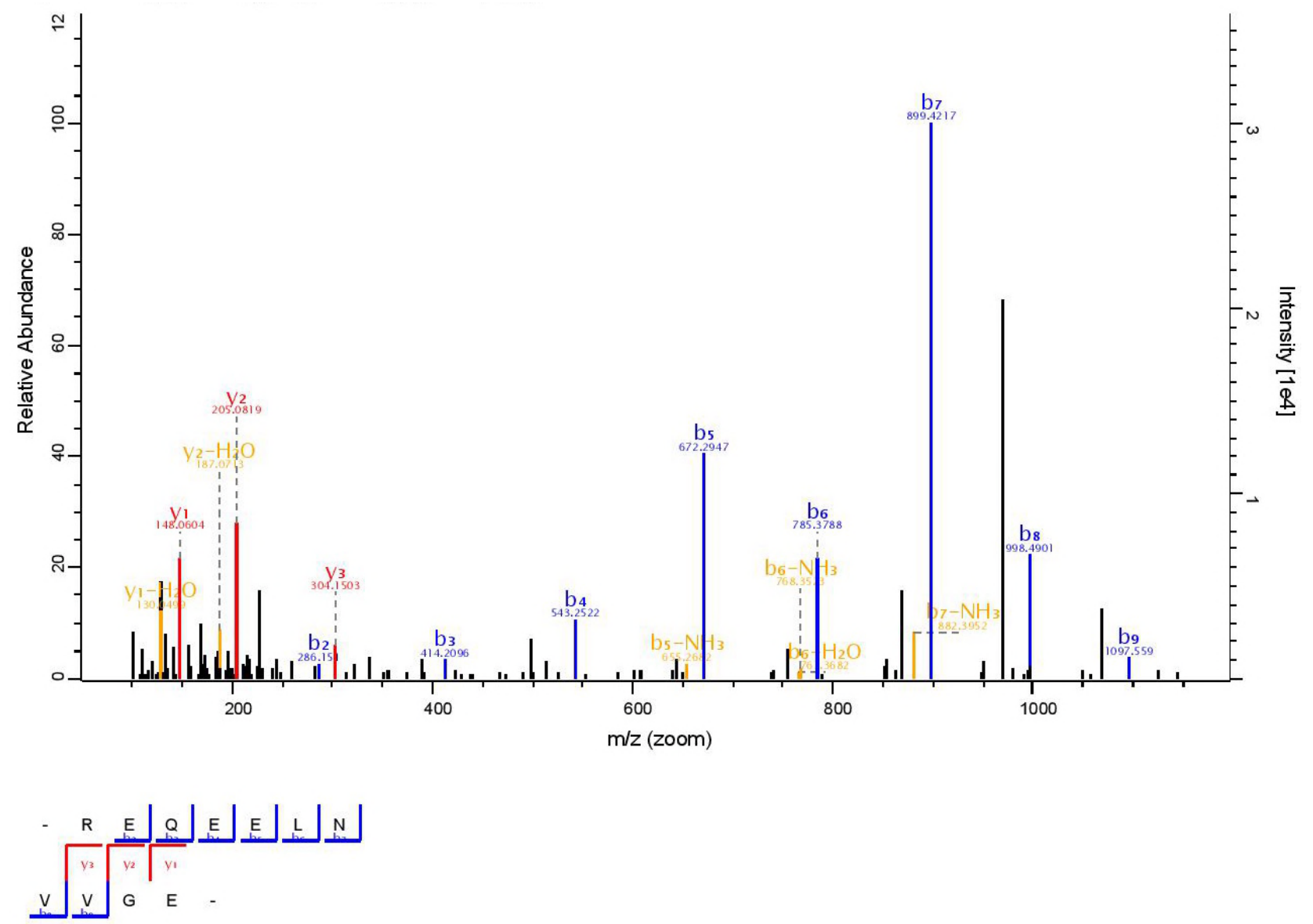
Figure 5 (E)
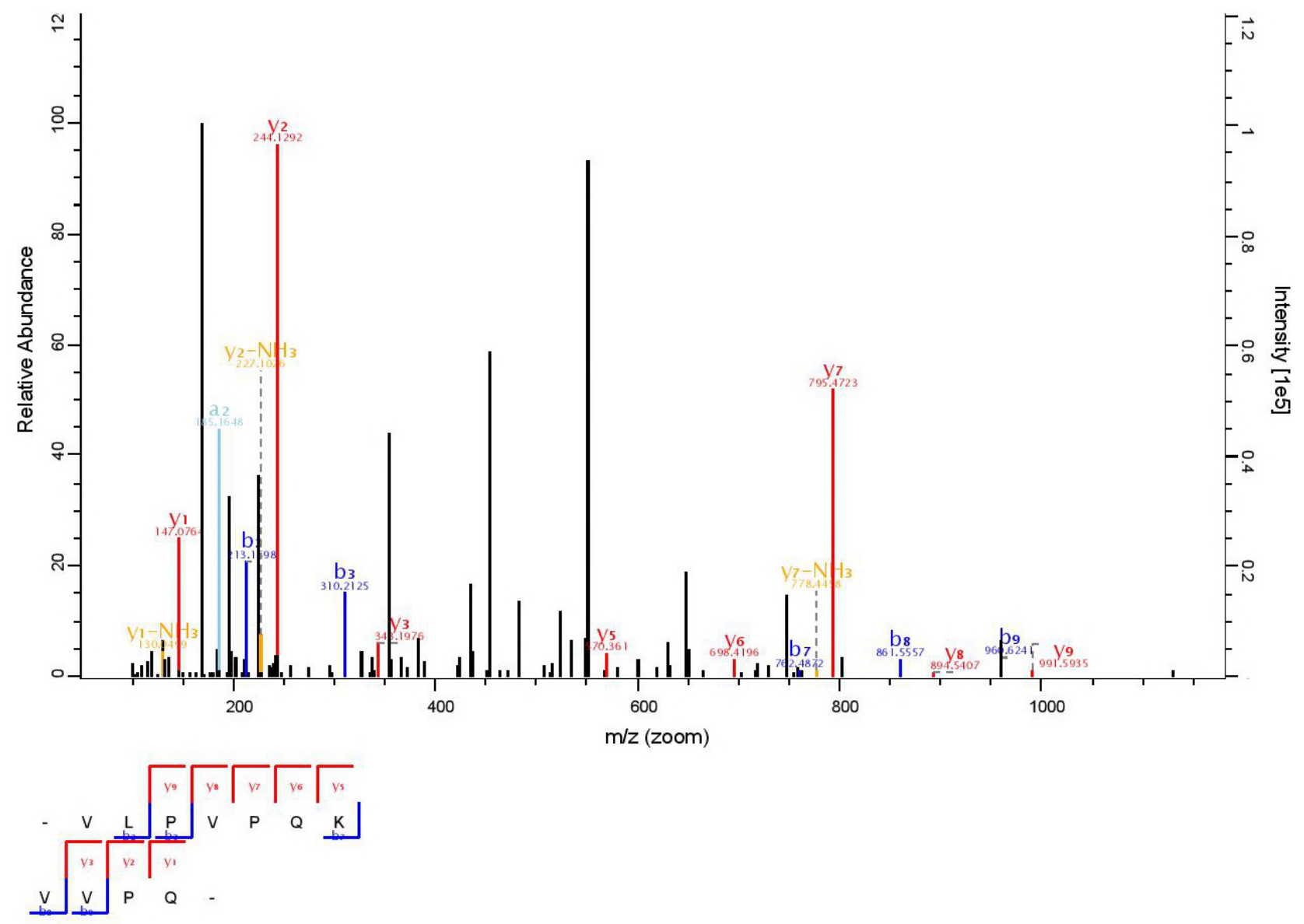